\title{
Geochronology of Mexican mineral deposits. VI: the Tayoltita low- sulfidation epithermal Ag-Au district, Durango and Sinaloa
}

Erme Enríquez, Alexander Iriondo, Antoni Camprubí

Erme Enríquez

ermegeo@gmail.com

Minera Canasil S.A. de C.V. Alhelí 142, Fraccionamiento Jardines de Durango, $34200 \mathrm{Du}-$ rango, Dgo., Mexico.

\section{Alexander Iriondo}

Centro de Geociencias, Universidad Nacional Autónoma de México. Boulevard Juriquilla 3001, 76230 Santiago de Querétaro, Qro., Mexico.

\section{Antoni Camprubí}

camprubitaga@gmail.com

Instituto de Geología, Universidad Nacional Autónoma de México. Ciudad Universitaria, 04510 Coyoacán, CDMX, Mexico.

BOL. SOC. GEOL. MEX. 2018

VOL. 70 NO. 2

P. $531-547$

http://dx.doi.org/10.18268/BSGM2018v70n2a13

Manuscript received: February 9, 2018 Corrected manuscript received: March 5, 2018 Manuscript accepted: March 11, 2018.

\section{ABSTRACT}

The Tayoltita district (Durango, Mexico) is one of the major silver and gold producers in the world with ove 745 million ounces of $\mathrm{Ag}$ and 11 million ounces of $\mathrm{Au}$ in the entire lifetime of the mine. These high-grade $\mathrm{Ag}$ - $\mathrm{Au}$ deposits are of low-sulfidation epithermal type, and formed during the final stages of igneous and hydrothermal activity of small Eocene quartz monzonitic and andesitic intrusions. The veins are hosted by tuffs, flows, and agglomerates of Paleocene age that belong to the Lowe Volcanic Complex of the Sierra Madre Occidental, and are unconformably overlain by the Miocene Upper Volcanic Supergroup. Three episodes of intrusion have taken place in the district. The presently available ages of the $\mathrm{Pi}$ axtla intrusions indicate that the batholithic complex wa emplaced between 46.31 and $45.1 \mathrm{Ma}$. The second event is represented by the so-called Intrusive andesite, which yielded ages that range between 39.9 and $37.9 \mathrm{Ma}$. The last intrusion event is represented by the Arana diorite. $\mathrm{K}$ - $\mathrm{Ar}$ ages of these rocks range between 38.1 and 36.6 $\mathrm{Ma}$. Ages obtained in this studv and in the available literature allow to establishing that the formation of epithermal veins in the district ranged between 41.01 and $31.9 \mathrm{Ma}$ Hydrothermal alteration and mineralization occurred within a 0.3 to $3.4 \mathrm{M}$ yr time-span after the emplacemen of the Intrusive andesite and the Arana diorite, respectively. Such intrusive events are generally acknowledged to have triggered ore formation in this district, thus implying the genetic association between the intrusive rocks and the epithermal deposits. The available ${ }^{40} \mathrm{Ar} /{ }^{39} \mathrm{Ar}$ and $\mathrm{K}-\mathrm{Ar}$ ages of adularia from vein material indicate that vein formation occurred episodically in distinct periods separated by intervals of about 3.18 M.yr, albeit magmatic-hydrothermal activity in the area experienced few lull periods The total duration of mineralization from the margin to the center of the Tayoltita district was $\sim 10 \mathrm{M}$ yr, which makes it one of the longest lived known epithermal deposits. However, there is no apparent correlation between the longevity of epithermal deposits and their size.

The age of an unaltered tuff of the Upper Volcanic Supergroup that unconformably overlies the Lower Volcanic Complex of the Sierra Madre Occidental indicates that tilting of the units and the activity of the paleo-hydrother mal system had ceased by $20.3 \mathrm{Ma}$. The temporal and spatial coincidence of volcanism, faulting, and high-grade mineralization may reflect the importance of contributions from deeper fluid reservoirs containing magmatic components or highly exchanged meteoric waters. In this sense, it is worth noting that the $0.3 \mathrm{M}$.yr. time-span between the emplacement of hypabyssal rocks and im mediately subsequent epithermal mineralization is much narrower than the common $\sim 2$ M.yr. time-span in most (low and intermediate sulfidation) epithermal deposits in Mexico that are proven to be associated with magmatic fluids, as it is the case of the giant deposits in the Fresnillo district. The short time-span suggests that the emplacement of hypabyssal rocks and epithermal deposit was known to date to have occurred in association with high-sulfidation deposits alone.

Keywords: Tayoltita, epithermal, low sulfidation, Ar/Ar ages, timing of mineralization, magmatic-hydrothermal cycling, Sierra Madre Occidental.

\section{RESUMEN}

El distrito de Tayoltita (Durango, México) es uno de los mayores productores de plata y oro en el mundo con más de 745 millones de onzas de Ag y 11 millones de onzas de Au producidos durante la historia de estas minas. Estos depósitos de alta ley de Ag-Au pertenecen al tipo epitermal de baja sulfuración, y se formaron durante Los últimos estadios de la actividad ignea e hidrotermal de pequeñas intrusiones cuarzo monzoníticas y andesíticas del Eoceno. Las vetas se encuentran encajonadas por tobas, flujos, y aglomerados del Paleoceno, pertenecientes al Grupo Volcánico Inferior de la Siera Madre Occidental, y son cubiertos discordantemente por rocas más recientes de la Secuencia Volcánica Superior, del Mioceno. En el distrito se produjeron tres episodios de intrusiones. Las edades actualmente disponibles de las intrusiones Piaxtla indican que el complejo se emplazó entre 46.31 y $45.1 \mathrm{Ma}$. El segundo evento está representado por la denominada andesita Intrusiva, con edades entre 39.9 y $37.9 \mathrm{Ma}$. El último evento intrusivo está representado por la diorita Arana. Las edades $K-A r$ de estas rocas varian entre 38.1 y 36.6 Ma. Las edades obtenidas en el presente estudio y en la bibliografia disponible permiten establecer que la formación de las vetas epitermales en el distrito se produjo entre 41.01 y 31.9 Ma. Las alteraciones y mineralizaciones hidrotermales se produjeron entre 0.3 y 3.4 millones de años tras el emplazamiento de la andesita Intrusiva y la diorita Arana, respectivamente. Se acepta generalmente que dichos eventos intrusivos detonaron la formación de menas en este distrito, lo cual implica la existencia de una asociación genética entre las rocas intrusivas y los depósitos epitermales. Las edades disponibles mediante ${ }^{40} \mathrm{Ar}{ }^{39} \mathrm{Ar}$ y $\mathrm{K}$-Ar en adularia procedente de vetas indica que la formación de las vetas se produjo de forma episódica en diferentes periodos separados por intervalos de unos 3.18 millones de años, aunque la actividad magmática-hidrotermal en el área experimentó escasos periodos de inactividad. La duración total de la mineralización desde la periferia a la porción central del distrito de Tayoltita fue de $\sim 10$ millones de años, lo que lo identifica como uno de los depósitos epitermales conocidos más longevos en el mundo. Sin embargo, no se aprecia una correlación entre la longevidad de los depósitos y su tamaño. La edad de una toba inalterada del Supergrupo Volcánico Superior que cubre de forma discordante al Complejo Volcánico Inferior de la Sierra Madre Occidental indica que el basculamiento de las rocas y la actividad del paleo-sistema hidrotermal habian cesado en 20.3 Ma. La coincidencia temporal y espacial del volcanismo, el fallamiento, y las mineralizaciones de alta ley puede ser el reflejo de la importancia de las contribuciones de fluidos profundos con componentes magmáticas o aguas meteóricas con un grado elevado de interacción con el substrato. En este sentido, es destacable que el periodo de 0.3 millones de años entre el emplazamiento de las rocas hipabisales y el de las inmediatamente subsiguientes mineralizaciones epitermales es mucho menor que el periodo de $\sim 2$ millones de años común en muchos depósitos epitermales (de sulfuración baja e intermedia) en México en que se ha comprobado su asociación con fluidos magmáticos, como en el caso de los depósitos gigantes del distrito de Fresnillo. Tal grado de proximidad temporal entre el emplazamiento de rocas hipabisales y depósitos epitermales era conocida hasta el momento sólo en asociación con depósitos de sulfuración alta.

Palabras clave: Tayoltita, epitermal, baja sulfuración, edades Ar/Ar, temporalidad de mineralización, ciclicidad magmática-hidrotermal, Sierra Madre Occidental. 


\section{Introduction}

The Tayoltita district is located on the central-western margin of the Sierra Madre Occidental volcanic province, about $125 \mathrm{~km}$ northeast of Mazatlán, Sinaloa, and $150 \mathrm{~km}$ west of Durango City (Figure 1). Mining activity began with the Spaniards in 1757, who operated the mines on a small scale until the War for Independence in 1810. By 1883, American investors took control of the mining operations and exploited all the mines in the district. In 1978, the properties were acquired by Mexican miners, and mining operations have been kept active until the present. Total production from the district is estimated to exceed $23.2 \times 10^{6} \mathrm{~kg} \mathrm{Ag}$, and $3.53 \times 10^{3} \mathrm{~kg} \mathrm{Au}$ (Henshaw, 1953; Smith and Hall, 1974; Enriquez, 1995; Albinson et al., 2001; Enriquez and Rivera, 2001).

The mineral wealth in the Tayoltita district is found in epithermal veins (dominantly of low sulfidation type with minor intermediate sulfidation stages), which constitute one of the largest deposits of their kind in Mexico. In the view of the co-evolution in time and space of Cenozoic magmatism and magmatic-hydrothermal ore deposits in Mexico (Camprubí, 2013) the epithermal deposits at Tayoltita, not unlike other large epithermal deposits (i.e. those in the Pachuca-Real del Monte district), may be regarded as some sort of "anomaly". They are counted among the oldest known in Mexico (Eocene), although the most prospective epoch for epithermal deposits is the Oligocene. Also, the most prospective areas for magmatic-hydrothermal deposits are the fault zones around the Mesa Central region (Nieto-Samaniego et al., 2005, 2007; Camprubí, 2013), which are the result of the reactivation of older structures, possibly associated with the suture zone between the Guerrero composite terrane and the Mexican mainland (Camprubí, 2013, 2017). In contrast with the latter, the Tayoltita deposits are seemingly associated with Laramide structures (Horner and Enriquez,

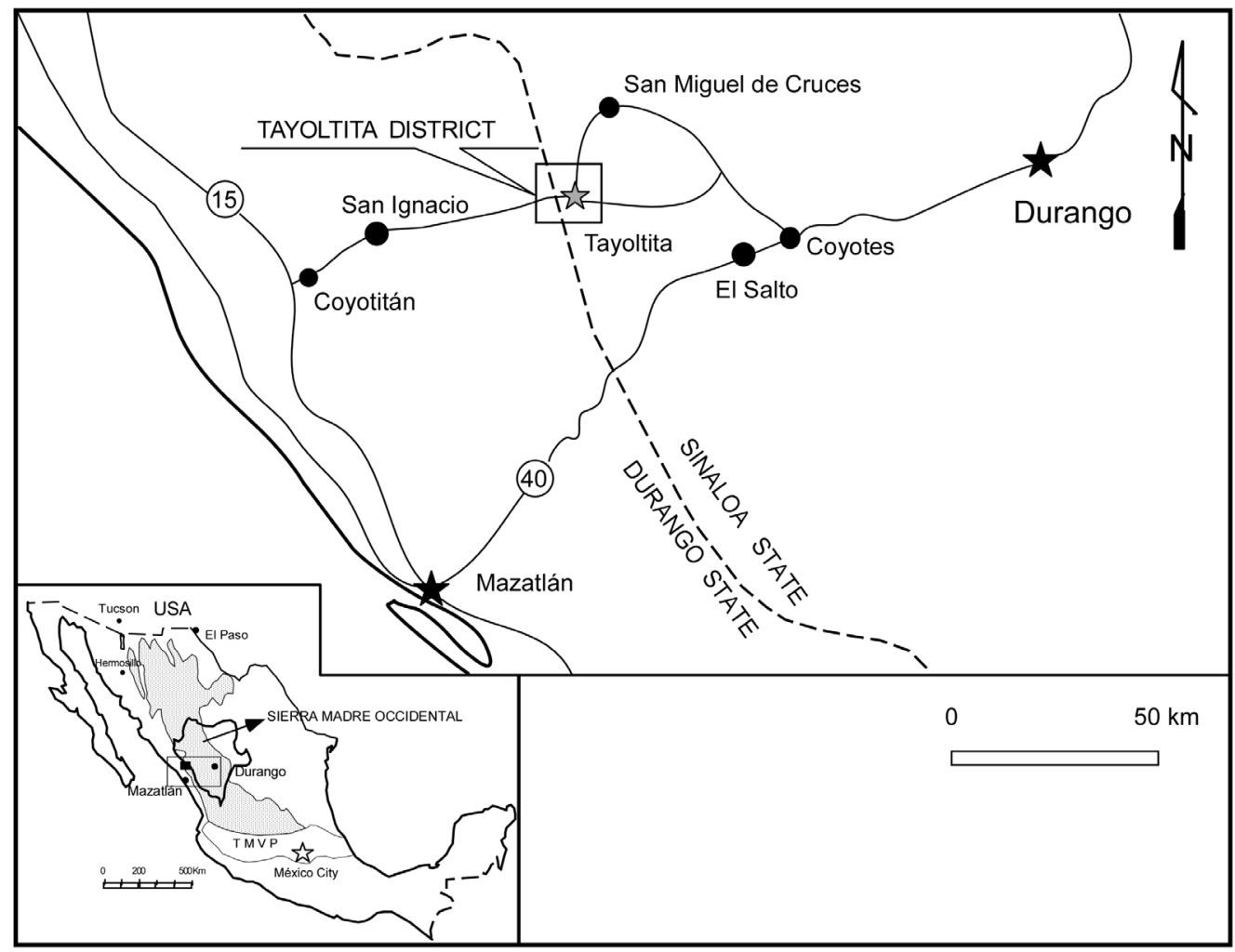

Figure 1 Map showing the location of the Tayoltita (or San Dimas) district, at the central-western edge of the Sierra Madre Occidental Volcanic Province. 
1999) that have no visible link with such important crustal discontinuity. Thus, the Tayoltita deposits is in need of additional structural, petrogenetic, and geochronologic studies.

Although the Tayoltita district is an important producer of precious metals, scarce research has been conducted concerning the age of mineralization. Previous reports include those by Randall (1971), Henry (1975), Henry and Fredrikson (1987), and Enriquez and Rivera (2001), which summarized the district geology and some ages of the host rocks and epithermal vein material. Our study relies upon new ages of the host Piaxtla intrusive bodies and veins that lacked proper dating and can constrain the temporal and genetic relationship between magmatism and epithermal precious-metal mineralization in the Tayoltita district.

\section{District geology and ore deposits}

The general geology of the area has been the subject of careful studies by Davidson (1932), Henshaw (1953), Nemeth (1976), Smith and Hall (1974), Smith et al. (1982), Clarke (1986), Clarke and Titley (1988), and Enriquez (1995). Two volcanic successions of overall $\sim 3500 \mathrm{~m}$ in thickness are separated by an erosional and depositional unconformity (Figure 2). The Lower Volcanic Complex is formed mainly by andesites and rhyolites of $\mathrm{Pa}$ leocene age and is intruded by younger members of a granitic to granodioritic batholithic complex. Two younger quartz monzonitic and andesitic intrusions cropping out and exposed underground are called locally the Arana diorite and Intrusive andesite respectively (Smith and Hall, 1974).

Five major north-northwest trending normal faults divide the district into four tilted fault blocks generally dipping $35^{\circ}$ to the east (Figure 2 ). The faults are in most cases post-ore in age, and offset the Lower Volcanic Complex (LVC) and Upper
Volcanic Supergroup (UVS). All the major faults exhibit NE-SW extension, and dips that vary from nearly vertical (Peña Fault) to less than 55 (Guamuchil Fault; Horner, 1998). They also vary in their magnitude of displacement, between $150 \mathrm{~m}$ (Peña and Arana faults) and more than $1500 \mathrm{~m}$ (Guamuchil Fault).

The veins were formed in association with relatively low salinity fluids (Albinson et al., 2001) in two distinct fault systems: the first comprises E-W striking veins (Figure 2), and the second is represented by NNE-SSW striking veins (Horner, 1998). Pinching and swelling, horse tailing, splitting and sigmoid structures are frequently observed throughout the district. The thickness of mineralized structures ranges between centimetric veinlets and $15 \mathrm{~m}$ thick veins, with an average of about $1.5 \mathrm{~m}$. They can be followed between a few meters and more than $1500 \mathrm{~m}$ underground. Ore shoots exhibit variable strike lengths that range between 5 and $600 \mathrm{~m}$. However, most ore shoots average $150 \mathrm{~m}$ along the strike and $200 \mathrm{~m}$ down dip. Three major stages of mineralization have been recognized in the district (Davidson, 1932; Henshaw, 1953; Smith et al., 1982): (1) early stage, (2) ore stage, (3) late quartz stage. Three distinct sub-stages of the ore stage have been identified in the veins of the district: (1) quartz-chlorite-adularia, (2) quartz-rhodonite, and (3) quartz-calcite (Clarke, 1986; Enriquez and Rivera, 2001). Ore grade mineralization always occurs in these sub-stages.

Overlying and postdating the LVC and the epithermal deposits in this area is the unaltered UVS. The UVS consists of $2000 \mathrm{~m}$ of post-ore andesites and ignimbrites (Henshaw, 1953; McDowell and Keizer, 1977) that are locally known as Capping Rhyolite. Enriquez and Rivera (2001) obtained $\mathrm{K}-\mathrm{Ar}$ ages for the lower andesitic unit of $24.5 \pm 0.9$ $\mathrm{Ma}$, and $20.3 \pm 0.8 \mathrm{Ma}$ for the upper ignimbrite unit. Radiometric ages ranging from 28.3 to 32.1 


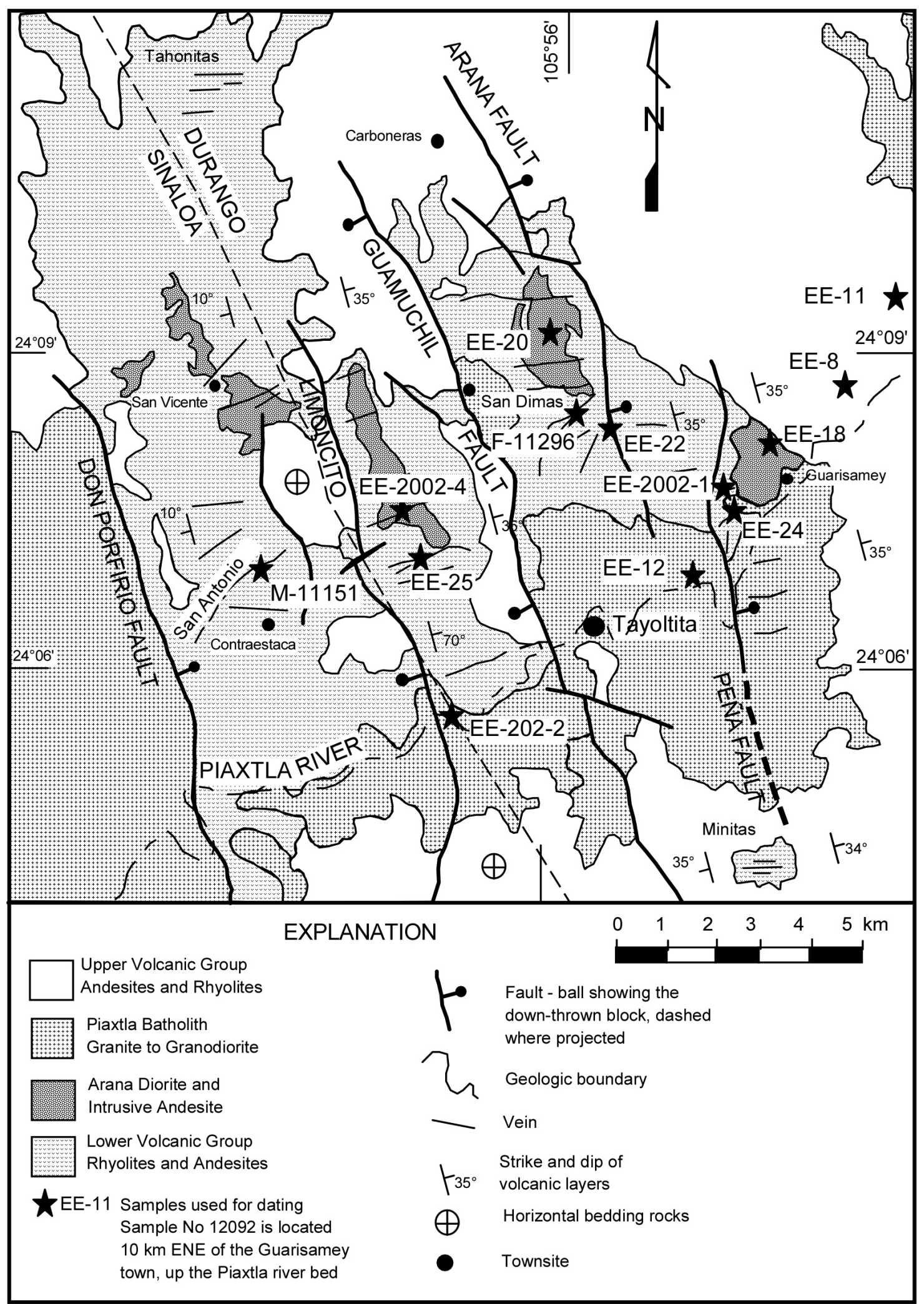

Figure 2 Geologic map of the Tayoltita district showing the distribution of Tertiary igneous rocks, major faults, and epithermal veins. Stars denote the location of samples from which geochronological data are available. Modified from Henshaw (1953), Smith and Hall (1974), and Clarke (1986). 
Ma have been reported for this volcanic sequence $70 \mathrm{~km}$ south of the Tayoltita district (McDowell and Keizer, 1977).

\section{Sampling and ${ }^{40} \mathrm{Ar} /{ }^{39} \mathrm{Ar}$ dating}

Sampling was performed at the surface and underground. Localities are shown in Figure 2. Also, samples are shown in the diagrammatic geologic section of the district to indicate the relationship between rocks and veins (Figure 3). Pure mineral separates of biotite from the Piaxtla intrusive and adularia from vein material of the Santo Niño and Cristina epithermal veins of the Tayoltita district was dated by ${ }^{40} \mathrm{Ar} /{ }^{39} \mathrm{Ar}$ geochronology (Figure 4 and Table 1). Adularia and biotite crystals that ranged in size from 250 to $180 \mu \mathrm{m}$ were separated using heavy liquids and hand picking to a purity of $>99 \%$. The samples were washed in acetone, alcohol, and deionized water in an ultrasonic cleaner to remove dust and then re-sieved by hand using a $180-\mu m$ sieve.
Aliquots of each sample $(\sim 20 \mathrm{mg})$ were packaged in copper capsules and sealed under vacuum in quartz tubes. The samples aliquots were then irradiated in package number KD29 for $20 \mathrm{~h}$ in the central thimble facility at the TRIGA reactor (GSTR) at the U.S. Geological Survey in Denver, Colorado. The monitor mineral used in the package was Fish Canyon Tuff sanidine (FCT-3) with an age of 27.79 Ma (Kunk et al., 1985; Cebula et al., 1986) relative to MMhb- 1 with an age of 519.4 $\pm 2.5 \mathrm{Ma}$ (Alexander et al., 1978; Dalrymple et al., 1981). The type of container and the geometry of the samples and standards were similar to that described by Snee et al. (1988).

The samples were analyzed at the U.S. Geological Survey Thermochronology lab in Denver, Colorado, using the ${ }^{40} \mathrm{Ar} /{ }^{39} \mathrm{Ar}$ step-heating method and a VG Isotopes 1200B mass spectrometer fitted with an electron multiplier. For additional information on the analytical procedure see Kunk et al. (2001). The analyzed samples yielded isochron ages at $46.30 \pm 0.68 \mathrm{Ma}$ for the Piaxtla intrusive (total fusion age of $46.31 \pm 0.13 \mathrm{Ma}$ in biotite), hereby

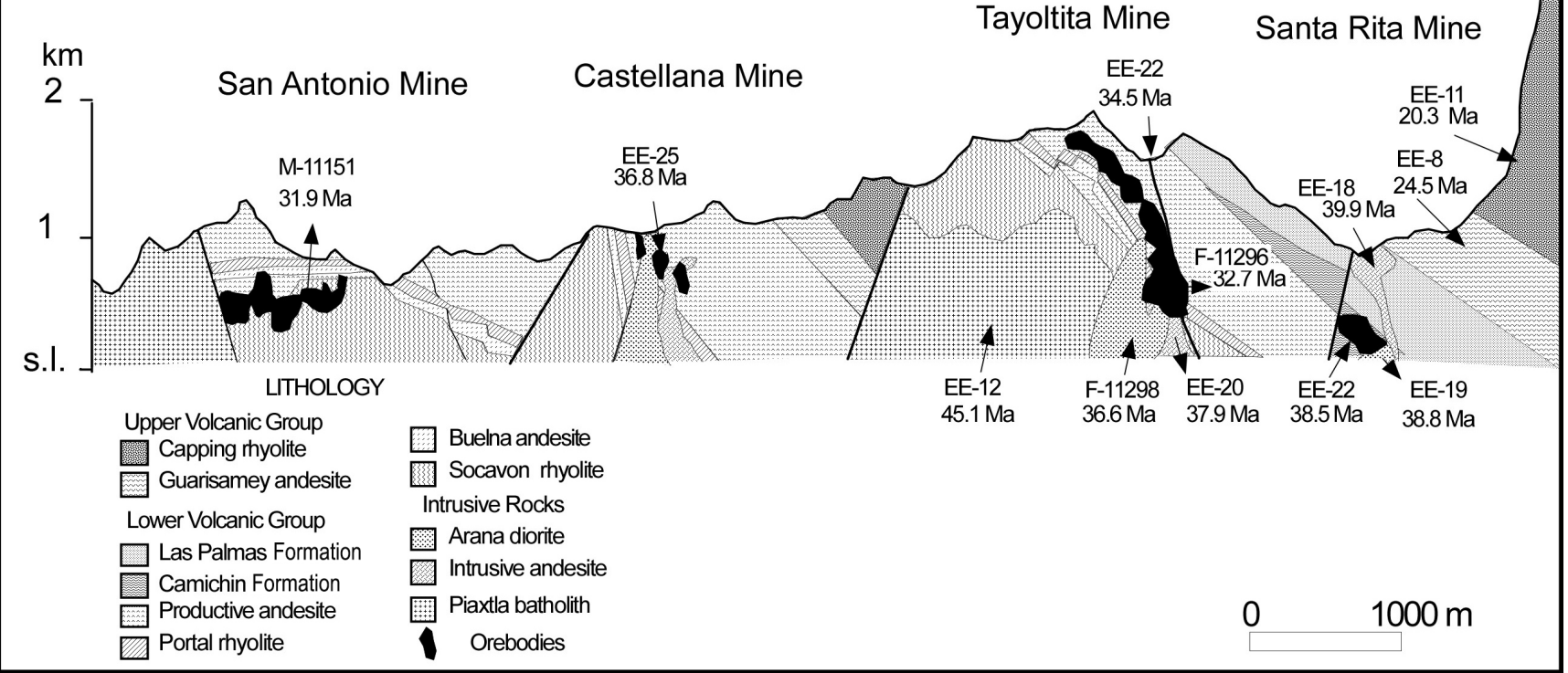

Figure 3 Diagrammatic section across the San Dimas district, illustrating the relative position of dated units and veins. Vertical scale has been exaggerated. Horizontal distances are to scale. Ages of rocks in the Tayoltita district as of Enriquez and Rivera (2001) are also listed in Table 2. 
Table $1 .{ }^{40} \mathrm{Ar} /{ }^{39} \mathrm{Ar}$ step-heating data for host and mineralization in Tayoltita, Durango, Mexico.

\begin{tabular}{|c|c|c|c|c|c|c|c|c|c|}
\hline Step & $\begin{array}{l}\text { Temp. } \\
{ }^{\circ} \mathrm{C}\end{array}$ & $\begin{array}{l}\%^{39} \mathrm{Ar} \\
\text { of total }\end{array}$ & $\begin{array}{c}\text { Radiogenic } \\
\text { Yield (\%) }\end{array}$ & $\begin{array}{c}{ }^{39} \mathrm{Ar}_{\mathrm{k}} \\
(\mathrm{moles})\end{array}$ & ${ }^{{ }^{40}} \underline{\mathrm{Ar}}$ & $\begin{array}{c}\text { Apparent } \\
\text { K/Ca }\end{array}$ & $\begin{array}{c}\text { Apparent } \\
\mathrm{K} / \mathrm{Cl}\end{array}$ & $\begin{array}{l}\text { Apparent } \\
\text { Age (Ma) }\end{array}$ & $\begin{array}{l}\text { Error } \\
\text { (Ma) }\end{array}$ \\
\hline$E E-2002-2$ & Biotite & Piaxtla granite & $J=0.003742$ & $0.50 \%$ & $9.3 \mathrm{mg}$ & \#80KD28 & & & \\
\hline A & 800 & 3.1 & 86.8 & $2.00 \mathrm{E}-14$ & 6.539 & 10 & 65 & \multicolumn{2}{|c|}{$43.61 \pm 0.69$} \\
\hline B & 900 & 19.4 & 97.8 & $1.23 \mathrm{E}-13$ & 6.930 & 81 & 76 & \multicolumn{2}{|c|}{$46.19 \pm 0.12$} \\
\hline C & 1000 & 12.6 & 99.4 & $8.02 \mathrm{E}-14$ & 6.935 & 52 & 76 & \multicolumn{2}{|c|}{$46.22 \pm 0.20$} \\
\hline D & 1100 & 10.2 & 95.7 & $6.48 \mathrm{E}-14$ & 6.872 & 11 & 72 & \multicolumn{2}{|c|}{$45.81 \pm 1.45$} \\
\hline $\mathbf{E}$ & 1200 & 54.7 & 96.1 & $3.48 \mathrm{E}-13$ & 6.877 & 76 & 70 & \multicolumn{2}{|c|}{$45.84 \pm 0.05$} \\
\hline Total Gas & & 100 & 96.5 & $6.36 \mathrm{E}-13$ & 6.930 & 65 & 72 & \multirow{2}{*}{\multicolumn{2}{|c|}{$\begin{array}{l}46.19 \\
\mathbf{4 5 . 8 6} \pm \mathbf{0 . 2 5}\end{array}$}} \\
\hline & \multicolumn{5}{|c|}{$77.5 \%$ of gas on plateau in 1000 through $1200{ }^{\circ} \mathrm{C}$ steps } & \multicolumn{2}{|c|}{ Plateau Age $=$} & & \\
\hline$E E-2002-2$ & \multicolumn{3}{|c|}{ Biotite total fusion } & $0.003741 \pm$ & $w t$ & \multicolumn{2}{|c|}{ \#79KD28 } & & \\
\hline A & 1650 & 100.0 & 98.0 & $1.96 \mathrm{E}-13$ & 6.950 & 57 & 60 & \multicolumn{2}{|c|}{$46.31 \pm 0.13$} \\
\hline$E E-2002-4$ & Adularia & Veta Santo Ni & $J=0.003$ & $9 \pm 0.50 \%$ & $=22.3 \mathrm{~m}$ & $\# 82 K D 28$ & & & \\
\hline A & 850 & 9.0 & 88.8 & $1.07 \mathrm{E}-13$ & 5.645 & 33 & 1237 & \multicolumn{2}{|c|}{$37.68 \pm 0.09$} \\
\hline B & 950 & 10.0 & 97.5 & $1.20 \mathrm{E}-13$ & 6.121 & 70 & 3848 & \multicolumn{2}{|c|}{$40.82 \pm 0.08$} \\
\hline C & 1050 & 11.4 & 98.9 & $1.37 \mathrm{E}-13$ & 6.231 & 101 & 6725 & \multicolumn{2}{|c|}{$41.55 \pm 0.07$} \\
\hline D & 1150 & 12.4 & 98.9 & $1.48 \mathrm{E}-13$ & 6.253 & 120 & 6163 & \multicolumn{2}{|c|}{$41.70 \pm 0.06$} \\
\hline $\mathbf{E}$ & 1250 & 10.4 & 97.2 & $1.25 \mathrm{E}-13$ & 6.212 & 96 & 250 & \multicolumn{2}{|c|}{$41.42 \pm 0.08$} \\
\hline $\mathbf{F}$ & 1300 & 8.1 & 92.4 & $9.68 \mathrm{E}-13$ & 6.115 & 77 & 1504 & \multicolumn{2}{|c|}{$40.78 \pm 0.10$} \\
\hline G & 1325 & 10.3 & 88.5 & $1.23 \mathrm{E}-13$ & 6.051 & 95 & 1766 & \multicolumn{2}{|c|}{$40.36 \pm 0.08$} \\
\hline H & 1350 & 14.5 & 87.7 & $1.74 \mathrm{E}-13$ & 6.067 & 152 & 1709 & \multicolumn{2}{|c|}{$40.47 \pm 0.06$} \\
\hline I & 1375 & 13.8 & 88.2 & $1.65 \mathrm{E}-13$ & 6.089 & 150 & 1850 & \multicolumn{2}{|c|}{$40.61 \pm 0.07$} \\
\hline \multirow[t]{2}{*}{ Total Gas } & & 100 & 93.0 & $2.07 \mathrm{E}-12$ & 6.159 & 105 & 2862 & \multirow{2}{*}{\multicolumn{2}{|c|}{$\begin{array}{l}41.08 \\
\mathbf{4 1 . 0 1} \pm \mathbf{0 . 2 3}\end{array}$}} \\
\hline & \multicolumn{5}{|c|}{$91.0 \%$ of gas on plateau-like average in 950 through $1375^{\circ} \mathrm{C}$ steps } & \multicolumn{2}{|c|}{ Average Age = } & & \\
\hline$E E-2002-1$ & Adularia & Veta Cristina & $J=0.003738$ & $0.50 \% \quad x$ & $21.0 \mathrm{mg}$ & \#81KD28 & & \multirow{2}{*}{\multicolumn{2}{|c|}{$33.39 \pm 0.09$}} \\
\hline A & 850 & 8.9 & 88.5 & $1.10 \mathrm{E}-13$ & 4.997 & 59 & 1839 & & \\
\hline B & 950 & 8.8 & 93.1 & $1.09 \mathrm{E}-13$ & 5.587 & 61 & 2721 & 37.28 & \pm 0.09 \\
\hline C & 1050 & 8.6 & 97.3 & $1.06 \mathrm{E}-13$ & 5.841 & 83 & 3637 & 38.96 & \pm 0.09 \\
\hline D & 1100 & 5.3 & 97.9 & $6.52 \mathrm{E}-14$ & 5.849 & 60 & 2440 & 39.02 & $\pm \mathbf{0 . 1 3}$ \\
\hline $\mathbf{E}$ & 1150 & 4.6 & 97.3 & $5.68 \mathrm{E}-14$ & 5.809 & 42 & 1602 & 38.75 & \pm 0.15 \\
\hline $\mathbf{F}$ & 1200 & 4.1 & 94.8 & $5.03 \mathrm{E}-14$ & 5.699 & 39 & 87 & 38.02 & \pm 0.17 \\
\hline G & 1225 & 3.2 & 92.7 & $3.91 \mathrm{E}-14$ & 5.692 & 32 & 590 & 37.98 & \pm 0.24 \\
\hline H & 1250 & 3.0 & 90.2 & $3.75 \mathrm{E}-14$ & 5.645 & 37 & 1182 & 37.67 & \pm 0.24 \\
\hline I & 1300 & 6.0 & 84.3 & $7.39 \mathrm{E}-14$ & 5.683 & 151 & 1014 & 37.92 & $\pm \mathbf{0 . 3 9}$ \\
\hline $\mathbf{J}$ & 1350 & 17.3 & 77.0 & $2.14 \mathrm{E}-13$ & 5.556 & 141 & 1086 & 37.08 & \pm 0.05 \\
\hline $\mathbf{K}$ & 1400 & 25.6 & 76.7 & $3.17 \mathrm{E}-13$ & 5.620 & 301 & 1093 & $\mathbf{3 7 . 5 0}$ & \pm 0.05 \\
\hline $\mathbf{L}$ & 1450 & 4.7 & 75.4 & $5.85 \mathrm{E}-14$ & 5.743 & 31 & 826 & 38.32 & \pm 0.14 \\
\hline Total Gas & & 100 & 85.1 & $1.24 \mathrm{E}-12$ & 5.625 & 138 & 1542 & 37.54 & \\
\hline & $82.3 \%$ of $g a$ & on plateau-like a & erage in 1050 & rough $1450^{\circ}$ & & & erage Age = & 37.83 & \pm 0.21 \\
\hline
\end{tabular}

Ages calculated assuming an initial ${ }^{40} \mathrm{Ar} /{ }^{36} \mathrm{Ar}=295.5 \pm 0$.

All precision estimates are at the one sigma level of precision.

Ages of individual steps do not include error in the irradiation parameter $\mathrm{J}$.

No error is calculated for the total gas age. 
Table 2. Ages of volcanic/subvolcanic rocks and epithermal deposits in Tayoltita, Durango, Mexico.

\begin{tabular}{|c|c|c|c|c|c|}
\hline Sample Number & Lithology & Material & Method & Age $\pm \sigma(\mathbf{M a})$ & References \\
\hline \multicolumn{6}{|l|}{ Ag-Au veins } \\
\hline M-11151 & San Antonio vein & sericite & $\mathrm{K}-\mathrm{Ar}$ & $31.9 \pm 0.8$ & Enriquez and Rivera (2001) \\
\hline F-11296 & San Luis vein & adularia & $\mathrm{K}-\mathrm{Ar}$ & $32.7 \pm 0.9$ & Enriquez and Rivera (2001) \\
\hline EE-22 & Arana vein system & adularia & $\mathrm{K}-\mathrm{Ar}$ & $34.5 \pm 0.9$ & Enriquez and Rivera (2001) \\
\hline EE-25 & Castellana vein & adularia & $\mathrm{K}-\mathrm{Ar}$ & $35.8 \pm 1.0$ & Enriquez and Rivera (2001) \\
\hline EE-2002-1 & Cristina vein & adularia & $\mathrm{Ar} / \mathrm{Ar}$ & $37.83 \pm 0.21$ & This study \\
\hline \multirow[t]{2}{*}{ EE-24 } & Patricia-2 vein & adularia & $\mathrm{K}-\mathrm{Ar}$ & $38.5 \pm 1.0$ & Enriquez and Rivera (2001) \\
\hline & Arana vein system & adularia & $\mathrm{K}-\mathrm{Ar}$ & $40 \pm 0.3$ & Henry (1975) \\
\hline EE-2002-4 & Santo Niño vein & adularia & $\mathrm{Ar} / \mathrm{Ar}$ & $41.01 \pm 0.23$ & This study \\
\hline \multicolumn{6}{|c|}{ Intrusive and volcanic rocks } \\
\hline EE-8 & Andesite LVG & plagioclase & $\mathrm{K}-\mathrm{Ar}$ & $33.7 \pm 0.9$ & Enriquez and Rivera (2001) \\
\hline F-11298 & Arana diorite & K-feldspar & $\mathrm{K}-\mathrm{Ar}$ & $36.6 \pm 1.0$ & Enriquez and Rivera (2001) \\
\hline EE-20 & Intrusive andesite & K-feldspar & $\mathrm{K}-\mathrm{Ar}$ & $37.9 \pm 1.0$ & Enriquez and Rivera (2001) \\
\hline EE-19 & Arana diorite & K-feldspar & $\mathrm{K}-\mathrm{Ar}$ & $38.8 \pm 1.0$ & Enriquez and Rivera (2001) \\
\hline EE-18 & Intrusive andesite & K-feldspar & $\mathrm{K}-\mathrm{Ar}$ & $39.9 \pm 1.0$ & Enriquez and Rivera (2001) \\
\hline EE-14 & Rhyolite LVG & K-feldspar & $\mathrm{K}-\mathrm{Ar}$ & $39.9 \pm 1.1$ & Enriquez and Rivera (2001) \\
\hline EE-12 & Piaxtla intrusion & biotite & $\mathrm{K}-\mathrm{Ar}$ & $45.1 \pm 1.0$ & Enriquez and Rivera (2001) \\
\hline 12092 & Corral stock & biotite & $\mathrm{K}-\mathrm{Ar}$ & $45.9 \pm 1.0$ & Enriquez and Rivera (2001) \\
\hline EE-2002-2 & Piaxtla intrusion & biotite & $\mathrm{Ar} / \mathrm{Ar}$ & $46.31 \pm 0.13$ & This study \\
\hline
\end{tabular}

Key: LVG = Lower Volcanic Complex of the Sierra Madre Occidental.

interpreted as its age of crystallization, at $41.20 \pm$ $0.53 \mathrm{Ma}$ for the Santo Niño vein (plateau-like average age of $41.01 \pm 0.23 \mathrm{Ma}$ in adularia), and at $37.90 \pm 0.49 \mathrm{Ma}$ for the Cristina vein (plateau-like average age of $37.83 \pm 0.21 \mathrm{Ma}$ in adularia).

\section{Discussion}

\subsection{AGES OF VOLGANIC AND INTRUSIVE ROGKS}

The Lower Volcanic Complex (LVG) is formed mainly of andesites and rhyolites cropping out in a package of more than 1500 meters in thickness that are considered to be older than the Piaxtla batholith. Economic epithermal mineralization occurred throughout the district in this package of rocks. An attempt to date the rocks of the Lower Volcanic Complex resulted in younger ages than the Piaxtla batholith, a reflection of the extensive and pervasive hydrothermal alteration of the LVC throughout the district. Similar andesites belonging to the LVC were dated close to Durango City at 51.6 Ma by McDowell and Keizer (1977). At the Tayoltita district, the age of the so-called Productive andesite reported is $33.7 \pm 0.9 \mathrm{Ma}$, but this age is more likely to be related to some hydrothermal alteration of the rock than to a repre- 

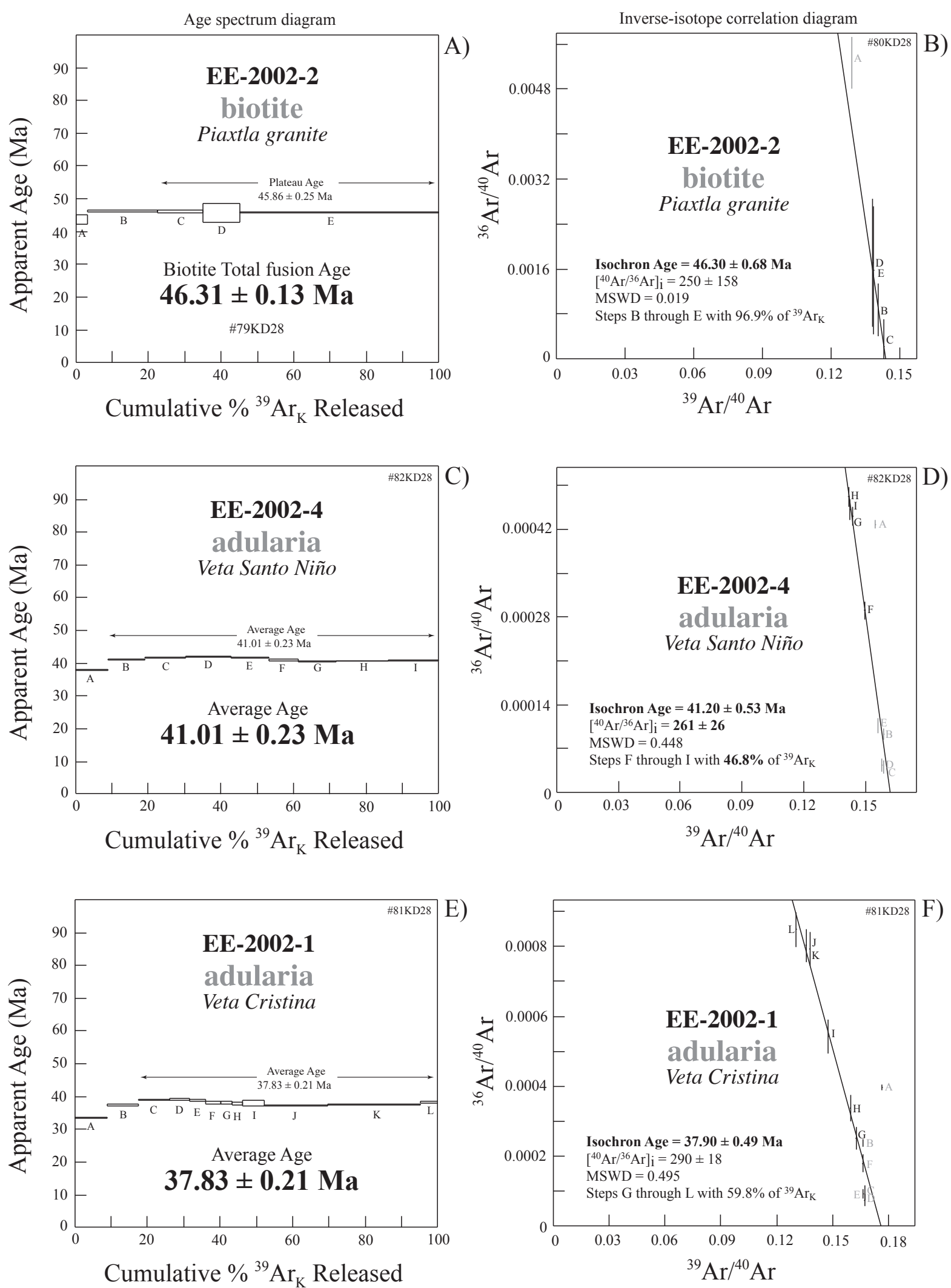

Figure $4{ }^{40} \mathrm{Ar} /{ }^{39} \mathrm{Ar}$ age spectra (A, C and E) and isochrons (B, D and F) for host rocks ( $A$ and B) and the Santo Niño (C and D) and Cristina ( $E$ and $F$ ) epithermal veins of the Tayoltita mining district, Durango. 
sentative age of the volcanic ensemble. Dating the LVC requires a different method for approaching the most likely age of the entire LVC.

Three plutonic events are represented by several intrusive bodies. The Piaxtla batholith rocks intruded the LVG in the canyons of the Barranca country. The compositions of the intrusions range from diorite, granodiorite to granite. These rocks were extensively examined by Henry (1975) and Henry and Fredrikson (1987). Their isotopic ages range from 102 to $45 \mathrm{Ma}$ in the western coastal area, and become younger eastward and inland to $45 \mathrm{Ma}$ (Henry, 1975). At Tayoltita, Henry (1975) reported K-Ar ages that ranged between 45 and $43 \mathrm{Ma}$. Two K-Ar ages of $45.1 \pm 1.1$ and 45.9 $\pm 1.2 \mathrm{Ma}$ were obtained by Enriquez and Rivera (2001) from the Piaxtla batholith and The Corral de Piedra stock, are consistent with the dates obtained by Henry (1975). The Intrusive andesite represents the second intrusive event. Two K-Ar ages for these rocks range between $39.9 \pm 1.0$ and $37.9 \pm 1.0 \mathrm{Ma}$ in fresh plagioclases (Enriquez and Rivera, 2001); however, these ages are uncertain and may be more related to alteration due to widespread hydrothermalism in the region. The Arana quartz monzonite followed the Intrusive andesite, and ages for these rocks range between $38.8 \pm 1.0$ and $36.6 \pm 1.0 \mathrm{Ma}$ (Table 2).

\subsection{AGES OF EPITHERMAL VEINS}

Seven ages are available for adularia- and sericite-bearing high-grade veins in the Tayoltita district that provide an age range for the main stages of mineralization (Table 2). A single date of 40 $\pm 0.3 \mathrm{Ma}$ was obtained by Henry (1975) for the Arana vein system. K-Ar data for the ore stage of vein formation ranged between $31.9 \pm 0.8$ and $38.6 \pm 1.0 \mathrm{Ma}$ (Enriquez and Rivera, 2001). The ${ }^{40} \mathrm{Ar} /{ }^{39} \mathrm{Ar}$ data obtained in this study for the orestage of vein formation range between $37.83 \pm$ 0.21 and $41.01 \pm 0.23 \mathrm{Ma}$. The veins from the western part of the district are younger than the veins from the eastern area; however, ${ }^{40} \mathrm{Ar} /{ }^{39} \mathrm{Ar}$ data obtained in this study suggests that hydro- thermal activity in the central part of the district began earlier than in the rest of the district (figures 2 and 5). The K-Ar data obtained by Henry (1975) could be interpreted to represent the earliest stage of mineralization. Data from altered host rocks are consistent with the range of ages for the veins. It turns out that the available ages for epithermal veins in the Tayoltita district (Table 2) span almost 10 M.yr. between the Bartonian (Eocene) and the Rupelian (Oligocene; Figure 5), and are distributed in at least five intrusive-hydrothermal activity cycles or episodes (early and late Bartonian, early and late Priabonian, and Rupelian). This was already known to be the longest active single epithermal deposit in Mexico (Enriquez and Rivera, 2001), but the age determinations in this study imply that the formation of epithermal deposits initiated at least $\sim 2.6$ M.yr. earlier than previously recognized. The existing age determinations for the volcanic rocks of the Upper Volcanic Supergroup that cap the epithermal deposits $(\leq 24.5$ Ma; Enriquez and Rivera, 2001) and those of the underlying Corral stock and Piaxtla intrusive $(\geq$ 45.1 Ma) still leave some room for further epithermal-producing paleo-hydrothermal activity in the area. The resulting minimum duration of the known hydrothermal activity is, for instance, twice the span of the available ages for the Zacatecas intermediate- to low sulfidation epithermal district ( 5 M.yr.; see figure 16 in Camprubí and Albinson, 2007), whose duration is second only to Tayoltita among Mexican epithermal deposits. In comparison, the duration of hydrothermal activity for these deposits dwarves the $\sim 2$ M.yr. period determined for other major epithermal districts in Mexico, such as the exceptionally large Fresnillo deposit in Zacatecas (Lang et al., 1988; Velador et al., 2010), the Sierra and Veta Madre deposits in Guanajuato (Martínez-Reyes et al., 2015), Taxco in Guerrero (Farfán-Panamá et al., 2015), and other deposits (Camprubí et al., 2003, 2016a, 2016b). The uncannily prolonged formation of epithermal deposits in Tayoltita was episodically fueled by re-activated magmatic activity, as the resulting intrusive bodies and veins intermingled in 


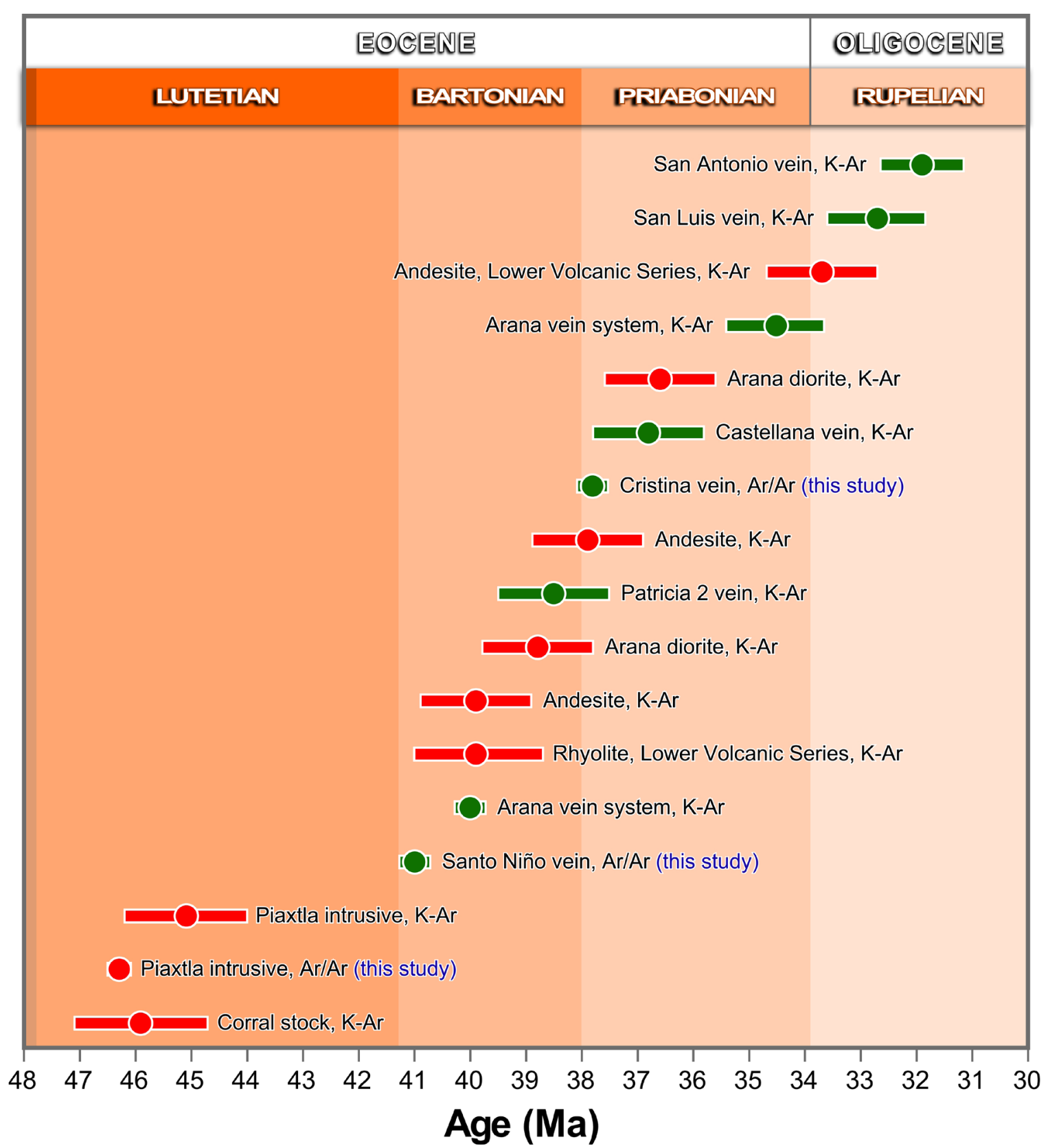

Figure 5 Distribution of the available geochronologic determinations in host rocks (in red) and vein material (in green) from epithermal deposits in the Tayoltita district, Durango. Circles represent average ages and bars standard deviations.

time (Figure 5). The reasons for such prolonged intrusive activity have not been determined at a local scale, but the minimum $\sim 41$ to $\sim 31$ Ma time bracket for the formation of the epithermal deposits of Tayoltita coincides with the last stages of the Lower Volcanic Complex of the Sierra Madre Occidental and the thickest deposits of volcanic rocks at the time (Henry and Fredrikson, 1987;
Ferrari et al., 2005, 2007). These deposits are part of a small Eocene belt in NW Durango, east of the San Luis-Tepehuanes fault zone (SLTFZ) that includes both epithermal and porphyry-type deposits (figure 7 in Camprubí, 2013). They also harbinger the Oligocene metallogenic epoch, which is the most productive in terms of number and size of ore deposits in Mexico (Camprubí, 2013), and is 
associated with the climactic stage of volcanism in the Sierra Madre Occidental (Ferrari et al., 2005, 2007). Additionally, this region experienced important E-W and ENE-WSW strike-slip and normal faulting at the end of the Eocene (Horner and Enriquez, 1999). Therefore, the long-lasting and continuous, albeit episodic, hydrothermal activity that produced the epithermal deposits of Tayoltita is associated with an exceptional (at its time) hypabyssal and volcanic activity whose emplacement was seemingly controlled by a major strikeslip corridor. The paramount example in Mexico of focused magmatic and hydrothermal activity is the neighboring SLTFZ (Nieto-Samaniego et al., 2005, 2007).

Similar long-lasting epithermal deposits are Yanacocha in Perú (Longo et al., 2010) and Cerro Bayo in Chile (Poblete et al., 2014). Yanacocha, possibly the largest high-sulfidation epithermal deposit known hitherto, formed in five cycles of volcanism/subvolcanism followed by hydrothermal activity that span no less than $\sim 5$ M.yr. Cerro Bayo, a low-sulfidation epithermal district, formed during 33 M.yr. (including long periods of inactivity) as a result of long-lasting continental extension, and the duration of the longest episode for the formation of epithermal mineralization is 13 M.yr. The sizes or metal endowment of epithermal deposits do not correlate well with the duration of the associated hydrothermal activity: both relatively small or large resources may form during very variable periods of time, regardless of the subtype of epithermal deposit to which they belong (Table 3).

The dominantly low-sulfidation epithermal veins in Tayoltita, as other similar deposits in Mexico (Lang et al., 1988; McKee et al., 1992; Camprubí et al., 2003; Camprubí and Albinson, 2007; Velador et al., 2010; Martínez-Reyes et al., 2015) and elsewhere (Warren et al., 2008; Li et al., 2016) typically record a $\sim 2$ M.yr. bracket between the youngest intrusive rock before the emplacement of the veins and the latter themselves. Such is the case of the span between the emplacement of the Arana intrusive and the eponymous vein, with $\mathrm{K}$-Ar ages at $36.6 \pm 1.0$ and $34.5 \pm 0.9 \mathrm{Ma}$, respectively (Enriquez and Rivera, 2001; see Table 2 and Figure 4). The pertinacious recurrence of such time bracket in many epithermal deposits can be interpreted as due to the progressive deepening of the emplacement sites of intrusive bodies as their parental magmatism wanes, similarly to porphyry-type deposits (e.g., within $\sim 0.7$ M.yr. in Bingham Canyon; Redmond and Einaudi, 2010) that would be due to the cooling-down and exhaustion of the magmatic chambers that fed the intrusive cycles (see figure 4 in Sillitoe, 2010). Depending on the size of magmatic chambers and the regional structural dynamics, these cycles of intrusion and subsequent hydrothermal activity can extend the life of porphyry systems up to a few million years (Chiaradia et al., 2013). However, not even porphyry systems have been proven to attain the exceptionally long-lasting activity of the Tayoltita epithermal deposits.

Besides the general case mentioned above, the study area contains compelling evidence for the simultaneous emplacement (within the range of uncertainty of geochronological data; Figure 5) of several intrusive rocks and epithermal veins at distances that range between 5 and less than 2 $\mathrm{km}$. That is the case of the so-called Intrusive andesite and the Cristina and Castellana veins (up to $\sim 5 \mathrm{~km}$ distant), another andesite intrusive and the San Luis vein ( $\sim \mathrm{km}$ distant) and, remarkably, part of the Arana diorite and the conterminous Patricia-2 vein. Although there are no available geochemical data that support the entrainment of magmatic fluids into the epithermal environment, the Arana diorite and the Patricia-2 vein are as nearly conterminous in time as they are in space: the average age for the diorite precedes that of the vein by merely $\sim 0.3 \mathrm{Ma}$. This tight relationship in time and space between the magmatic and hydrothermal activity that begot these epithermal deposits can be attributed to a genetic link, although 
Table 3. Selected examples of duration of hydrothermal activity and size of the resources of the resulting epithermal deposits.

\begin{tabular}{|c|c|c|c|c|c|c|c|}
\hline $\begin{array}{l}\text { District or } \\
\text { deposit }\end{array}$ & Location & $\begin{array}{l}\text { Subtype of } \\
\text { epithermal } \\
\text { deposit }\end{array}$ & $\begin{array}{c}\text { Ages of } \\
\text { epithermal } \\
\text { deposits (Ma) }\end{array}$ & $\begin{array}{l}\text { Approxi-mate } \\
\text { age span (Ma) }\end{array}$ & $\begin{array}{l}\text { Relatively } \\
\text { continuous } \\
\text { hydrothermal } \\
\text { activity? }\end{array}$ & $\begin{array}{l}\text { Deposit size, tonnage and grades } \\
\text { or known production }\end{array}$ & References \\
\hline Tayoltita & $\begin{array}{l}\text { Durango, } \\
\text { Mexico }\end{array}$ & LS (minor IS) & $\begin{array}{c}41.01 \pm 0.23 \text { to } \\
31.9 \pm 0.8\end{array}$ & 10 & yes & $\begin{array}{c}\text { Large; >19 Mt @ } 500 \mathrm{~g} / \mathrm{t} \mathrm{Ag} \mathrm{\&} 8 \\
\mathrm{~g} / \mathrm{t} \mathrm{Au} ; 10.2 \mathrm{Moz} \mathrm{Ag} \& 6.5 \mathrm{koz} \mathrm{Au} \\
\text { as of } 2001\end{array}$ & $\begin{array}{l}\text { Henry (1975), Enriquez } \\
\text { and Rivera (2001), this } \\
\text { study. }\end{array}$ \\
\hline Zacatecas & $\begin{array}{l}\text { Zacatecas, } \\
\text { Mexico }\end{array}$ & IS to LS & 35.5 to 30.8 & 5 & yes & $\begin{array}{c}\text { Large; }>20 \mathrm{Mt} @ 750 \mathrm{Moz} \mathrm{Ag} \text { as of } \\
2001\end{array}$ & $\begin{array}{l}\text { Albinson et al. (2001), } \\
\text { Camprubí and Albinson } \\
\text { (2007). }\end{array}$ \\
\hline Fresnillo & $\begin{array}{l}\text { Zacatecas, } \\
\text { Mexico }\end{array}$ & IS (minor LS) & $\begin{array}{c}31.03 \pm 0.05 \text { to } \\
29.68 \pm 0.10\end{array}$ & 2 & yes & $\begin{array}{c}\text { Very large; }>60 \mathrm{Mt} @ 296 \mathrm{~g} / \mathrm{t} \mathrm{Ag} \mathrm{\&} \\
0.77 \mathrm{~g} / \mathrm{t} \mathrm{Au} \text { in current reserves; total } \\
\text { reserves of } 201.6 \mathrm{Moz} \mathrm{Ag}, 525 \mathrm{koz} \\
\mathrm{Au} \text { as of } 2015\left(^{*}\right) ; \text { a } 1 \mathrm{Goz} \text { resource } \\
\text { altogether }\end{array}$ & $\begin{array}{l}\text { Lang et al. (1998), } \\
\text { Velador et al. (2010). }\end{array}$ \\
\hline Guanajuato $(* *)$ & $\begin{array}{l}\text { Guanajuato, } \\
\text { Mexico }\end{array}$ & IS to LS & $\begin{array}{c}30.20 \pm 0.17 \text { to } \\
28.47 \pm 0.55\end{array}$ & 2 & yes & $\begin{array}{c}\text { Large; }>40 \mathrm{Mt} @ 850 \mathrm{~g} / \mathrm{t} \mathrm{Ag} \mathrm{\&} 4 \\
\mathrm{~g} / \mathrm{t} \mathrm{Au} \text { as of } 2001\end{array}$ & $\begin{array}{l}\text { Albinson et al. (2001), } \\
\text { Martínez-Reyes et al. } \\
\text { (2015). }\end{array}$ \\
\hline Taxco & $\begin{array}{l}\text { Guerrero, } \\
\text { Mexico }\end{array}$ & IS (minor LS) & $\begin{array}{c}34.96 \pm 0.19 \text { to } \\
\sim 33\end{array}$ & 2 & yes & $\begin{array}{c}\text { Large; }>30 \mathrm{Mt} @ 240 \mathrm{~g} / \mathrm{t} \mathrm{Ag} \mathrm{\&} \\
\sim 6 \% \mathrm{Zn}+\mathrm{Pb} \text { as of } 2001\end{array}$ & $\begin{array}{l}\text { Albinson et al. (2001), } \\
\text { Farfán-Panamá et al. } \\
\text { (2015). }\end{array}$ \\
\hline Yanacocha & Northern Perú & HS & $\begin{array}{c}13.56 \pm 0.24 \text { to } \\
8.40 \pm 0.06\end{array}$ & 5 & yes & $\begin{array}{c}\text { Very large; } 3125 \mathrm{Mt} @ \sim 90 \mathrm{~g} / \mathrm{t} \mathrm{Ag} ; \\
70 \mathrm{Moz} \mathrm{Au} \text { as of } 2008\end{array}$ & $\begin{array}{l}\text { Longo et al. (2010), Teal } \\
\text { and Benavides (2010). }\end{array}$ \\
\hline & & & \multicolumn{2}{|c|}{ (Overall $33 \mathrm{Ma}$ ) } & & & \\
\hline Cerro Bayo & $\begin{array}{l}\text { Patagonia, } \\
\text { Chile }\end{array}$ & LS & $\begin{array}{l}3 \text { stages: } \\
\text { a) } 144 \text { to } 142 \\
\text { b) } 137 \text { to } 124 \\
\text { c) } 114 \text { to } 111\end{array}$ & $\begin{array}{c}2 \\
13 \\
3\end{array}$ & no & $\begin{array}{c}\text { Small; } 1.6 \mathrm{Mt} @ 3.2 \mathrm{~g} / \mathrm{t} \mathrm{Au} \& 373 \\
\mathrm{~g} / \mathrm{t} \mathrm{Ag} \text { as of } 2014\end{array}$ & $\begin{array}{l}\text { Poblete } \text { et al. }(2014) \text {, and } \\
\text { references therein. }\end{array}$ \\
\hline El Peñón & Northern Chile & LS & $\begin{array}{c}52.95 \pm 0.40 \text { to } \\
49.84 \pm 0.24\end{array}$ & 3 & yes & $\begin{array}{c}\text { Large; } 18 \mathrm{Mt} @ 12.23 \mathrm{~g} / \mathrm{t} \mathrm{Au} \mathrm{\&} \\
343.4 \mathrm{~g} / \mathrm{t} \mathrm{Ag} ; 7 \mathrm{Moz} \text { Au \& } 199 \mathrm{Moz} \\
\mathrm{Ag} \text { as of } 2008\end{array}$ & Warren et al. (2008). \\
\hline Banská Štiavnica & Slovakia & LS & $12.2(?)$ to 10.7 & 1.5 & yes & $\begin{array}{c}\text { Large; }>47 \mathrm{Mt} @ 4.8 \mathrm{~g} / \mathrm{t} \mathrm{Au}, 42 \mathrm{~g} / \mathrm{t} \\
\mathrm{Ag} \& 5.4 \% \mathrm{~Pb}+\mathrm{Zn} \text { as of } 1999\end{array}$ & $\begin{array}{l}\text { Prokofiev et al. (1999), } \\
\text { Chernyshev et al. (2013). }\end{array}$ \\
\hline Hishikari & Kyushu, Japan & LS & 1.21 to 0.60 & 0.6 & yes & 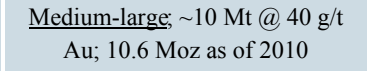 & $\begin{array}{l}\text { Sanematsu et al. (2005), } \\
\text { Tohma et al. (2010). }\end{array}$ \\
\hline Midas & $\begin{array}{l}\text { Nevada, } \\
\text { U.S.A. }\end{array}$ & LS & $\begin{array}{c}15.39 \pm 0.02 \text { to } \\
15.25 \pm 0.05\end{array}$ & 0.2 & yes & $\frac{\text { Small; } 3.4 \mathrm{Mt} @ 17.75 \mathrm{~g} / \mathrm{t} \text { Au as of }}{2004}$ & Leavitt et al. (2004). \\
\hline
\end{tabular}

Key: HS = high sulfidation; IS = intermediate sulfidation; LS = low sulfidation; Goz = giga ounces; koz = thousand ounces; Moz = million ounces.

Notes: (*) Fresnillo PLC (2018).

(**) Veta Madre and Sierra groups of veins alone. 
such implication is not proven. Until this study, similar degrees of "nearness" between epithermal deposits and their associated intrusive rocks have been described in study cases that belong exclusively to the high sulfidation subtype (e.g., Arribas et al., 1995; Valencia et al., 2005).

\section{Conclusions}

The new geochronological determinations for the Tayoltita epithermal deposit indicate that this deposit was formed between $41.01 \pm 0.23$ and 31.9 $\pm 0.8 \mathrm{Ma}$ (late Eocene to earliest Oligocene), although it is possible that these deposits are longer lived than the $\sim 10$ Ma bracket mentioned above. Therefore, the hydrothermal activity in Tayoltita records the longest duration known hitherto for epithermal deposits in Mexico, and one of the longest known elsewhere for this type of deposits. However, no clear correlation can be drawn between the duration of hydrothermal activity and the size or metal endowment of the resulting epithermal deposits.

The dated veins were produced after the emplacement of hypabyssal intrusions nearby $(\leq 5 \mathrm{~km}$ distant), in at least five cycles of intrusion and subsequent hydrothermal activity. In some cases, epithermal veins follow their youngest host intrusive rocks after a somewhat "classic" $\sim 2$ M.yr. gap, as in other intermediate- to low-sulfidation epithermal deposits. In other cases the gap between magmatic and hydrothermal activity can be as short as $\sim 0.3$ M.yr., which is an unusual feature for an epithermal deposit that does not belong to the high-sulfidation type.

It is implied that the long magmatic-hydrothermal history for these epithermal deposits requires no ordinary geological conditions, as epithermal deposits elsewhere are mostly much shorter-lived than those in Tayoltita. Such conditions are associ- ated with voluminous volcanic activity in the area during the late Eocene, which was focused by a long-lived regional-scale strike-slip corridor.

\section{Acknowledgements}

The authors wish to thank Michael Kunk for providing access and guidance to perform the geochronology studies at the U.S. Geological Survey Thermochronology Lab in Denver, Colorado. Funding for this study was originally provided by the Luismin S.A. de C.V. mining company, the former proprietary of the mines of Tayoltita. Primero Mining Corp., through Miguel Pérez, is wholeheartedly thanked for granting permission to publish the original data in this paper. Thomas Bissig is thanked for his handy insight of Andean epithermal deposits; Lisard Torró and Aldo Izaguirre conducted thorough formal reviews for the first version of this paper.

\section{References}

Albinson, T., Norman, D.I., Cole, D., Chomiak, B., 2001, Controls of formation on lowsulfidation epithermal deposits in Mexico: constraints from fluid inclusion and stable isotope data, in Albinson, T., Nelson, C.E. (eds.), New mines and discoveries in Mexico and Central America: Society of Economic Geologists Special Publication, 8, 1-32.

Alexander, E.C. Jr., Mickelson, G.M., Lanphere, M.A., 1978, Mmhb-1: a new ${ }^{40} \mathrm{Ar} /{ }^{39} \mathrm{Ar}$ dating standard, in Zartman, R.E. (ed.), Short papers of the fourth international conference, geochronology, cosmochronology, and isotope geology: U.S. Geological Survey Open-File Report, 78-701, 6-8. 
Arribas, A. Jr., Hedenquist, J.W., Itaya, T., Okada, T., Concepción, R.A., Garcia, J.S. Jr., 1995, Contemporaneous formation of adjacent porphyry and epithermal $\mathrm{Cu}-\mathrm{Au}$ deposits over 300 ka in northern Luzon, Philippines: Geology, 23(4), 337-340.

Camprubí, A., 2013, Tectonic and metallogenic history of Mexico, in Colpron, M., Bissig, T., Rusk, B.G., Thompson, J.F.H. (eds.), Tectonics, metallogeny, and discovery: the North American Cordillera and similar accretionary settings: Society of Economic Geologists Special Publication, 17, 201-243.

Camprubí, A., 2017, The metallogenic evolution in Mexico during the Mesozoic, and its bearing in the Cordillera of Western North America: Ore Geology Reviews, 81(P3), 1193-1214.

Camprubí, A., Albinson, T., 2007, Epithermal deposits in México - an update of current knowledge, and an empirical reclassification, in Alaniz-Álvarez, S.A., Nieto-Samaniego, A.F. (eds.), Geology of México: Celebrating the Centenary of the Geological Society of México: The Geological Society of America Special Paper, 422, 377-415.

Camprubí, A., Ferrari, L., Cosca, M.A., Cardellach, E., Canals, À., 2003, Ages of epithermal deposits in Mexico: regional significance and links with the evolution of Tertiary volcanism: Economic Geology, 98(5), 1029-1037.

Camprubí, A., Albinson, T., Iriondo, A., 2016a, Geochronology of Mexican mineral deposits. $\mathrm{V}$ : the Peñón Blanco epithermal deposit, Durango: Boletín de la Sociedad Geológica Mexicana, 68(2), 365-370.

Camprubí, A., Iriondo, A., López-Martínez, M., Ramos-Rosique, A., 2016b, Geochronology of Mexican mineral deposits. IV: the Cinco
Minas epithermal deposit, Jalisco: Boletín de la Sociedad Geológica Mexicana, 68(2), 357-364.

Cebula, G.T., Kunk, M.J., Mehnert, H.H., Naeser, G.W., Obradovich, J.D., Sutter, J.F., 1986, The Fish Canyon Tuff: A potential standard for the ${ }^{40} \mathrm{Ar} /{ }^{39} \mathrm{Ar}$ and fission track dating methods: Terra Cognita, 6, 140.

Chernyshev, I.V., Konečný, V., Lexa,J., Kovalenker, V.A., Jeleň, S., Lebedev, V.A., Goltsman, Y.V., 2013, K-Ar and Rb-Sr geochronology and evolution of the Śtiavnica stratovolcano (Central Slovakia): Geologica Carpathica, 64(4), 327-351.

Chiaradia, M., Schaltegger, U., Spikings, R., Wotzlaw, J.-F., Ovtcharova, M., 2013, How accurately can we date the duration of magmatic-hydrothermal events in porphyry systems?: Economic Geology, 108(4), 565-584.

Clarke, M., 1986, Hydrothermal geochemistry of $\mathrm{Ag}-\mathrm{Au}$ vein formation in the Tayoltita mine and San Dimas mining district, Durango and Sinaloa, Mexico: Tucson, Arizona, U.S.A., University of Arizona, Ph.D. Thesis, 151 p.

Clarke, M., Titley, S.R., 1988, Hydrothermal evolution in the formation of silver-gold veins in the Tayoltita mine, San Dimas District, Mexico: Economic Geology, 83(3), 1830-1840.

Dalrymple, G.B., Alexander, E.C. Jr., Lanphere, M.A., Kraker, G.P., 1981, Irradiation of samples for ${ }^{40} \mathrm{Ar} /{ }^{39} \mathrm{Ar}$ dating using the Geological Survey TRIGA reactor: U.S. Geological Survey Professional Paper, 1176 , $55 \mathrm{p}$.

Davidson, S., 1932, Geology and ore deposits of the Tayoltita, district of San Dimas, Durango, Mexico: Cambridge, U.S.A., Harvard University, Ph.D. Thesis, 172 p. 
Enriquez, E., 1995, Trace element zonation and temperature controls of the Tayoltita $\mathrm{Ag}-\mathrm{Au}$ fossil hydrothermal system, Tayoltita district, Durango, Mexico: Golden, Colorado, U.S.A., Colorado School of Mines, M.Sc. Thesis, $195 \mathrm{p}$.

Enriquez, E., Rivera, R., 2001, Timing of magmatic and hydrothermal activity in the San Dimas District, Durango, Mexico, in Albinson, T., Nelson, G.E. (eds.), New mines and discoveries in Mexico and Central America: Society of Economic Geologists Special Publication, 8, 33-38.

Farfán-Panamá, J.L., Camprubí, A., GonzálezPartida, E., Iriondo, A., González-Torres, E.A., 2015, Geochronology of Mexican mineral deposits. III: the Taxco epithermal deposits, Guerrero: Boletín de la Sociedad Geológica Mexicana, 67(2), 357-366.

Ferrari, L., Valencia-Moreno, M., Bryan, S., 2005, Magmatismo y tectónica en la Sierra Madre Occidental y su relación con la evolución de la margen occidental de Norteamérica: Boletín de la Sociedad Geológica Mexicana, 57(3), 343-378.

Ferrari, L., Valencia-Moreno, M., Bryan, S., 2007, Magmatism and tectonics of the Sierra Madre Occidental and its relation with the evolution of the western margin of North America, in Alaniz-Álvarez, S.A., NietoSamaniego, Á.F. (eds.), Geology of México: Celebrating the Centenary of the Geological Society of México: Geological Society of America Special Paper, 422, 1-39.

Fresnillo PLC, 2018, Mines in Operation: Fresnillo: Mexico City, Mexico, available at $<$ http://www.fresnilloplc.com/what-we-do/ mines-in-operation/fresnillo/>, consulted on July, 2016.
Henry, C.D., 1975, Geology and geochronology of the granitic batholithic complex, Sinaloa, Mexico: Austin, Texas, U.S.A., University of Texas, Ph.D. Thesis, 158 p.

Henry, G.D., Fredrikson, G., 1987, Geology of part of southern Sinaloa, Mexico, adjacent to the Gulf of California: Geological Society of America, Map and Chart Series MCH063, $14 \mathrm{p}$.

Henshaw, P.C., 1953, Geology and ore deposits of the San Dimas district, Sinaloa and Durango: Tayoltita, Durango, Mexico, San Luis Mining Company, Private Report, 531 p.

Horner, J.T., 1998, Structural geology and exploration in the San Dimas district, Durango, México - An alternative geological model: Salzburg, Austria, University of Salzburg, Ph.D. Thesis, 120 p.

Horner, J.T., Enriquez, E., 1999, Epithermal precious metal mineralization in a strikeslip corridor: The San Dimas district, Durango, Mexico: Economic Geology, 94(8), 1375-1380.

Kunk, M.J., Sutter, J.F., Naeser, C.W., 1985, Highprecision ${ }^{40} \mathrm{Ar} /{ }^{39} \mathrm{Ar}$ ages of sanidine, biotite, hornblende, and plagioclase from the Fish Canyon tuff, San Juan volcanic field, Southcentral Colorado: Geological Society of America Abstracts with Programs, 17, 636.

Kunk, M.J., Winick, J.A., Stanley, J.O., 2001, ${ }^{40} \mathrm{Ar} /{ }^{39} \mathrm{Ar}$ age-spectrum and laser fusion data for volcanic rocks in west central Colorado: U.S. Geological Survey Open-File Report, 2001-472, $94 \mathrm{p}$.

Lang, B., Steinitz, G., Sawkins, FJ., Simmons, S.F., 1988, K-Ar age studies in the Fresnillo silver district, Zacatecas, Mexico: Economic Geology, 83(8), 1642-1646. 
Leavitt, E.D., Spell, T.L., Goldstrand, P.M., Arehart, G.B., 2004, Geochronology of the Midas low-sulfidation epithermal gold-silver deposit, Elko County, Nevada: Economic Geology, 99(8), 1665-1686.

Li, J.-X., Qin, K.-Z., Li, G.-M., Evans, N.J., Zhao, J.-X., Cao, M.-J., Huang, F., 2016, The Nadun $\mathrm{Cu}-\mathrm{Au}$ mineralization, central Tibet: Root of a high sulfidation epithermal deposit: Ore Geology Reviews, 78, 371-387.

Longo, A.A., Dilles, J.H., Grunder, A.L., Duncan, R., 2010, Evolution of calc-alkaline volcanism and associated hydrothermal gold deposits at Yanacocha, Peru: Economic Geology, 105(7), 1191-1241.

Martínez-Reyes, J.J., Camprubí, A., Uysal, I.T., Iriondo, A., González-Partida, E., 2015, Geochronology of Mexican mineral deposits. II: Veta Madre and Sierra epithermal vein systems, Guanajuato district: Boletín de la Sociedad Geológica Mexicana, 67(2), 349-355.

McDowell, F.W., Keizer, R.P., 1977, Timing of mid-Tertiary volcanism in the Sierra Madre Occidental between Durango City and Mazatlan, Mexico: Geological Society of America Bulletin, 88(10), 1479-1487.

McKee, E.H., Dreier,J.E., Noble, D.C., 1992, Early Miocene hydrothermal activity at PachucaReal del Monte, Mexico: an example of space-time association of volcanism and epithermal $\mathrm{Ag}-\mathrm{Au}$ vein mineralization: Economic Geology, 87(6), 1635-1637.

Nemeth, K.E., 1976, Petrography of the lower volcanic group Tayoltita-San Dimas district, Durango, Mexico: Austin, Texas, U.S.A., University of Texas, M.A. Thesis, 141 p.

Nieto-Samaniego, Á.F., Alaniz-Álvarez, S.A., Camprubí, A., 2005, La Mesa Central de México: estratigrafía, estructura y evolución tectónica cenozoica: Boletín de la Sociedad Geológica Mexicana, 57(3), 285-318.

Nieto-Samaniego, Á.F., Alaniz-Álvarez, S.A., Camprubí,A., 2007,Mesa Central of México: stratigraphy, structure and Cenozoic tectonic evolution, in Alaniz-Álvarez, S.A., NietoSamaniego, Á.F. (eds.), Geology of México: Celebrating the Centenary of the Geological Society of México: The Geological Society of America Special Paper, 422, 41-70.

Poblete, J.A., Bissig, T., Mortensen, J.K., Gabites, J., Friedman, R., Rodriguez, M., 2014, The Cerro Bayo district, Chilean Patagonia: Late Jurassic to Cretaceous magmatism and protracted history of epithermal $\mathrm{Ag}-\mathrm{Au}$ mineralization: Economic Geology, 109(2), 487-502.

Prokofiev, V., Kamenetsky, V.S., Kovalenker, V., Bodon, S.B., Jelen, S., 1999, Evolution of magmatic fluids at the Banska Stiavnica precious and base metal deposit, Slovakia; evidence from melt and fluid inclusions: Economic Geology, 94(6), 949-955.

Randall,J.A., 1971, Geology and geochemistry of upper Rio Piaxtla hypothermal deposits and their relationship to nearby precious metal veins: Unpublished report, Minas de San Luis, S.A. de G.V., 5 p.

Redmond, P.B., Einaudi, M.T., 2010, The Bingham Canyon porphyry $\mathrm{Cu}-\mathrm{Mo}-\mathrm{Au}$ deposit. I. Sequence of intrusions, vein formation, and sulfide deposition: Economic Geology, 105(1), 43-68.

Sanematsu, K., Duncan, R., Imai, A., Watanabe, K., 2005, Geochronological constraints using ${ }^{40} \mathrm{Ar} /{ }^{39} \mathrm{Ar}$ dating on the mineralization of the Hishikari epithermal gold deposit, Japan: Resource Geology, 55(3), 249-266.

Sillitoe, R.H., 2010, Porphyry copper systems: Economic Geology, 105(1), 3-41.

Smith, D.M. Jr., Hall, D.K., 1974, Geology of the Tayoltita mine, Durango, Mexico: American Institute of Mining, Metallurgical, and Petroleum Engineers, Preprint 74-I-308, 48 p.

Smith, D.M. Jr., Albinson, T., Sawkins, FJ., 1982, Geologic and fluid inclusion studies of the Tayoltita silver-gold vein deposit, Durango, Mexico: Economic Geology, 77, 1120-1145. 
Snee, L.W., Sutter, J.F., Kelly, W.C., 1988, Thermochronology of economic mineral deposits: Dating the stages of mineralization at Panasqueira, Portugal, by high precision ${ }^{40} \mathrm{Ar} /{ }^{39} \mathrm{Ar}$ age spectrum techniques on muscovite: Economic Geology, 83, 335-354.

Teal, L., Benavides, A., 2010, History and geologic overview of the Yanacocha mining district, Cajamarca, Peru: Economic Geology, 105(7), 1173-1190.

Tohma, Y., Imai, A., Sanematsu, K., Yonezu, K., Takahashi, R., Koyama, M., Sekine, R., Duncan, R., Watanabe, K., 2010, Characteristics and mineralization age of the Fukusen No. 1 vein, Hishikari epithermal gold deposits, southern Kyushu, Japan: Resource Geology, 60(4), 348-358.

Valencia, V.A., Ruiz, J., Barra, F., Gehrels, G., Ducea, M., Titley, S.R., Ochoa-Landin, L.,
2005, U-Pb zircon and Re-Os molybdenite geochronology from La Caridad porphyry copper deposit: Insights for the duration of magmatism and mineralization in the Nacozari District, Sonora, Mexico: Mineralium Deposita, 40(2), 175-191.

Velador, J.M., Heizler, M.T., Campbell, A.R., 2010, Timing of magmatic activity and mineralization and evidence of a long-lived hydrothermal system in the Fresnillo silver district, Mexico: constraints from ${ }^{40} \mathrm{Ar} /{ }^{39} \mathrm{Ar}$ geochronology: Economic Geology, 105(7), 1335-1349.

Warren, I., Archibald, D.A., Simmons, S.F., 2008, Geochronology of epithermal Au-Ag mineralization, magmatic-hydrothermal alteration, and supergene weathering in the El Peñón district, Northern Chile: Economic Geology, 103(4) 851-864. 